НАУКОВИЙ ВІСНИК

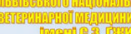

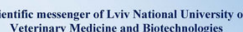

1

$\sqrt{3}$

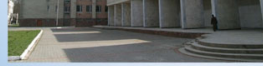

СЕРЯя: ВЕТЕРИНАРНН НАУКИ

Том 23 № 101

2021
Науковий вісник Дьвівського національного університету ветеринарної медицини та біотехнологій імені С.3. Гжицького. Серія: Ветеринарні науки

\author{
Scientific Messenger of Lviv National University \\ of Veterinary Medicine and Biotechnologies. \\ Series: Veterinary sciences
}

UDC 636.92:576.895.132.8

\title{
The effectiveness of the proposed method of culturing eggs of nematodes Passalurus ambiguus, parasitic in rabbits
}

\author{
V. O. Yevstafieva, A. A. Khorolskyi, V. V. Melnychuk \\ Poltava State Agrarian Academy, Poltava, Ukraine
}

Article info

Received 24.12.2020

Received in revised form 25.01.2021

Accepted 26.01.2021

Poltava State Agrarian Academy,

Skovorody Str., 1/3

Poltava, 36003, Ukraine

Tel.: +38-050-183-78-78

E-mail:evstva@ukr.net

\begin{abstract}
Yevstafieva, V. O., Khorolskyi, A. A., \& Melnychuk, V. V. (2021). The effectiveness of the proposed method of culturing eggs of nematodes Passalurus ambiguus, parasitic in rabbits. Scientific Messenger of Lviv National University of Veterinary Medicine and Biotechnologies. Series: Veterinary sciences, 23(101), 26-30. doi: 10.32718/nvlvet10105
\end{abstract}

Rabbit breeding is one of the promising branches of meat cattle breeding, and also plays an important role in supplying light industry with fur raw materials. One of the factors that ensure the efficient management of the industry and increase the production of rabbit products is the veterinary welfare of farms against parasitic diseases of rabbits, in particular - pasalurosis. It is necessary to prevent the development of the parasite at all stages in order to successfully control and prevent pasalurosis. The aim of the work was to improve and determine the effectiveness of the method of cultivation of Passalurus ambiguus eggs, which can be used to study the embryogenesis of the pathogen pasalurosis in rabbits, obtain a laboratory model of invasion, determine the disinvasive properties of disinvasive and disinfectants and agents. The proposed method of culturing P. ambiguus nematode eggs allows to take into account the sensitivity of eggs to moisture, allows to obtain a high yield of invasive eggs in the experimental culture, as well as to conduct microscopic examinations and microphotography without removing eggs from the substrate in which cultivation takes place. Eggs of P. ambiguus were obtained from the gonads of females of the pathogen pasalurosis, which were removed by helminthic dissection of the colon of rabbits. The proposed method is based on the use of nutrient environment for the cultivation of P. ambiguus eggs. Studies have shown that the improved method was more effective than the well-known method, where as a substrate for the cultivation of Pasaluris eggs used saline. With the use of the improved method, the invasive stage reaches more than $71 \%$ of Pasaluris eggs, which is $38.75 \%$ more $(P<0.001)$ than with the use of the well-known method of cultivation. The obtained results of the conducted research activities lead to further, deeper study of questions concerning biological features of embryonic development of the causative agent of passalurosis, and also disinvasive efficiency of modern disinfectants concerning $P$. ambiguus eggs.

Key words: rabbits, passalurosis, Passalurus ambiguus, nematode eggs, cultivation method, efficiency.

\section{Ефективність запропонованого способу культивування яєць нематод Passalurus ambiguus, що паразитують у кролів}

\author{
В. О. Євстаф’єва, А. А. Хорольський, В. В. Мельничук
}

Полтавська державна аграрна академія, м. Полтава, Україна

\footnotetext{
Кролівництво є однією з перспективних галузей м'ясного тваринництва, а також відіграє важливу роль у постачанні легкоі промисловості хутровою сировиною. Одним із факторів, щуо забезпечують ефективне ведення галузі та збільшення виробництва продукиї кролівництва, є ветеринарне благополуччя господарств щьоо паразитарних хвороб кролів, зокрема - пасалурозу. 3 метою успішної боротьби та профілактики пасалурозу необхідно унеможливити розвиток паразита на всіх його стадіях. Метою роботи було удосконалити та визначити ефективність способу культивування яєць Рassalurus aтbiguи, який може бути використаний з метою вивчення особливостей ембріогенезу збудника пасалурозу кролів, отримання лабораторної моделі інвазї, визначення дезінвазійних властивостей дезінвазійних та дезінфікуючих речовин і засобів. Запропонований спосіб культивування яєць
} 
нематод P. ambiguиs дозволяє враховувати чутливість яєиьь до вологи, дає змогу отримати високий вихід інвазійних яєиь в дослідній культурі, а також проводити мікроскопічні дослідження та мікрофотозйомку без вилучення яєць з субстрату, в якому відбувається культивування. Яйия Р. атbiguиs отримували з гонад самок збудника пасалурозу, шо були вилучені за гельмінтологічного розтину товстих кишок кролів. Запропонований спосіб трунтується на використанні для культивування яєць Р. атьіgии живильного середовища. Проведеними дослідженнями встановлено, шуо удосконалений спосіб виявився ефективнішим, ніж загальновідомий метод, де як субстрат для культивування яєць пасалурисів використовували фізіологічний розчин. За використання удосконаленого способу інвазійної стадї досягають понад $71 \%$ яєць пасалурисів, шуо на 38, 75 \% більше (Р < 0,001), ніж за використання загальновідомого способу культивування. Отримані результати проведених досліджень зумовлюють подальше, більш глибоке вивчення питань щодо біологічних особливостей ембріонального розвитку збудника пасалурозу, а також дезінвазійної ефективності сучасних дезінфікуючих засобів щуодо яєць P. ambiguиs.

Ключові слова: кролі, пасалуроз, Раssalurus ambiguиs, яйчя нематод, метод культивування, ефективність.

\section{Вступ}

Кролівництво - перспективна галузь тваринництва, що виробляє сировину і різноманітну продукцію для харчової та легкої промисловості, рослинництва та медицини. Відомо, що м'ясо кролів соковите, ніжне, має низьку калорійність за значного вмісту повноцінного білка, належить до білого м'яса і рекомендується як дієтичний продукт. Кролячий жир легкоплавкий і за якістю переважає яловичий, баранячий та свинячий. Крім того, кролів використовують у медицині й ветеринарії як лабораторних тварин для проведення досліджень 3 випробовування фармакологічних препаратів та виготовлення вакцин (Dalle Zotte, 2002; Cullere \& Dalle Zotte, 2018; Li et al., 2018).

Одним із факторів, що забезпечують ефективне введення галузі та збільшення виробництва продукції кролівництва, $є$ ветеринарне благополуччя господарств щодо паразитарних хвороб кролів, зокрема пасалурозу (Robinson \& Chalmers, 2010; Hernandez et al., 2018; Abdel-Gaber et al., 2019; Mykhailiutenko et al., 2019). Так, на території Північно-Східної Шотландії 14,2 \% досліджених домашніх кролів були уражені збудником пасалурозу (Boag, 1985). В окремих регіонах Німеччини ураженість кролів Passalurus ambiguus становила $13,11 \%$, а на території Північно-Західного Ірану екстенсивність пасалурозної інвазії сягала $54 \%$ (Haupt \& Hartung, 1984; Hajipour \& Zavarshani, 2020).

При формуванні адаптацій і здатності до значного поширення паразитичних нематод серед популяції хазяїв велике значення має низка факторів, одним 3 яких є біологічні особливості видів, включаючи характер їх взаємодії із зовнішнім середовищем на всіх стадіях свого розвитку. До важливої біологічної адаптації нематод-геогельмінтів щодо збереження і розселення своєї популяції можна зарахувати екзогенний розвиток яєць паразитів у зовнішньому середовищі, тобто утворення 3 незрілого яйця інвазійного, здатного заразити дефінітивного хазяїна (Lee, 2002; Stroehlein et al., 2017).

Тому важливою умовою для ефективного забезпечення благополуччя щодо пасолурозу в кролівничих господарствах $\epsilon$ знання особливостей екзогенного розвитку яєць пасалурисів, що неможливо без проведення експериментальних досліджень на тесткультурах. Зокрема, існує спосіб культивування личинок і яєць гельмінтів та ооцист найпростіших, згідно 3 яким як субстрат для культивування використовують кристали аграрного гідрогелю (Mytrofanov et al., 2013). Також існує спосіб культивування яєць
Trichuris muris, згідно 3 яким яйця гельмінтів отримують із фекалій інвазованих збудником Trichuris muris мишей флотаційно-центрифужним методом (Astafiev et al., 1989). Водночас специфічних методів культивування яєць $P$. ambiguus у доступній літератуpi не знайдено. Тому метою роботи було удосконалити та визначити ефективність способу культивування яєць Passalurus ambiguus, який може бути використаний 3 метою вивчення ембріональних стадій розвитку збудника пасалурозу кролів, отримання лабораторної моделі інвазії, визначення дезінвазійних властивостей дезінвазійних та дезінфікуючих речовин і засобів.

\section{Матеріал і методи досліджень}

Роботу виконували упродовж 2020 року на базі лабораторії кафедри паразитології та ветеринарносанітарної експертизи Полтавської державної аграрної академії. Збір гельмінтів проводили методом повного гельмінтологічного розтину товстого відділу кишечника 78 кролів, що надходили із одноосібних селянських господарств Полтавської області (Skriabyn, 1928).

Яйця нематод $P$. ambiguus отримували з гонад caмок гельмінтів та змивали їх фізіологічним розчином в ступки, де проводили гомогенізацію. Отриману тест-культуру яєць пасалурисів культивували за удосконаленим способом, згідно 3 яким культуру яєць переносили на попередньо підготовлене годинникове скельце $з$ поживним середовищем, поміщали його в термостат за температури $35{ }^{\circ} \mathrm{C}$ й проводили культивування впродовж 3-5 діб.

3 метою встановлення ефективності запропонованого способу культивування яєць в умовах лабораторії при використанні однакового температурного режиму $\left(35^{\circ} \mathrm{C}\right)$ проведено експериментальне дослідження, в якому порівнювали удосконалений спосіб та загальновідому методику (Smirnov, 1927). Всього проведено 20 дослідів, в яких культивували яйця P. ambiguus 3 використанням різних субстратів за різними способами. Оцінювання проводили за показниками кількості інвазійних яєць на 5-у добу експерименту та яєць, що загинули або зупинилися в розвитку, шляхом мікроскопії культур із розрахунку на 100 підрахованих яєць.

Математичний аналіз отриманих даних проводили 3 використанням пакету прикладних програм Microsoft "EXCEL”. Розраховували середнє арифметичне (М) та його похибку (m). 


\section{Результати та їх обговорення}

Проведеними дослідженнями встановлено, що при застосуванні запропонованого способу культура яєць $P$. ambiguus, виділених з гонад самок пасалурисів, при внесенні на поживне середовище і за умов мікроскопічного дослідження виявилася добре просвітленою та зручною в підрахунку яєць у процесі їх подальшого ембріогенезу (рис. 1).

При проведенні порівняння ефективності запропонованого способу та загальновідомої методики за культивування яєць збудника пассалурозу кролів до інвазійної стадії виявлено показники, які характеризували переваги удосконаленого способу (табл. 1).

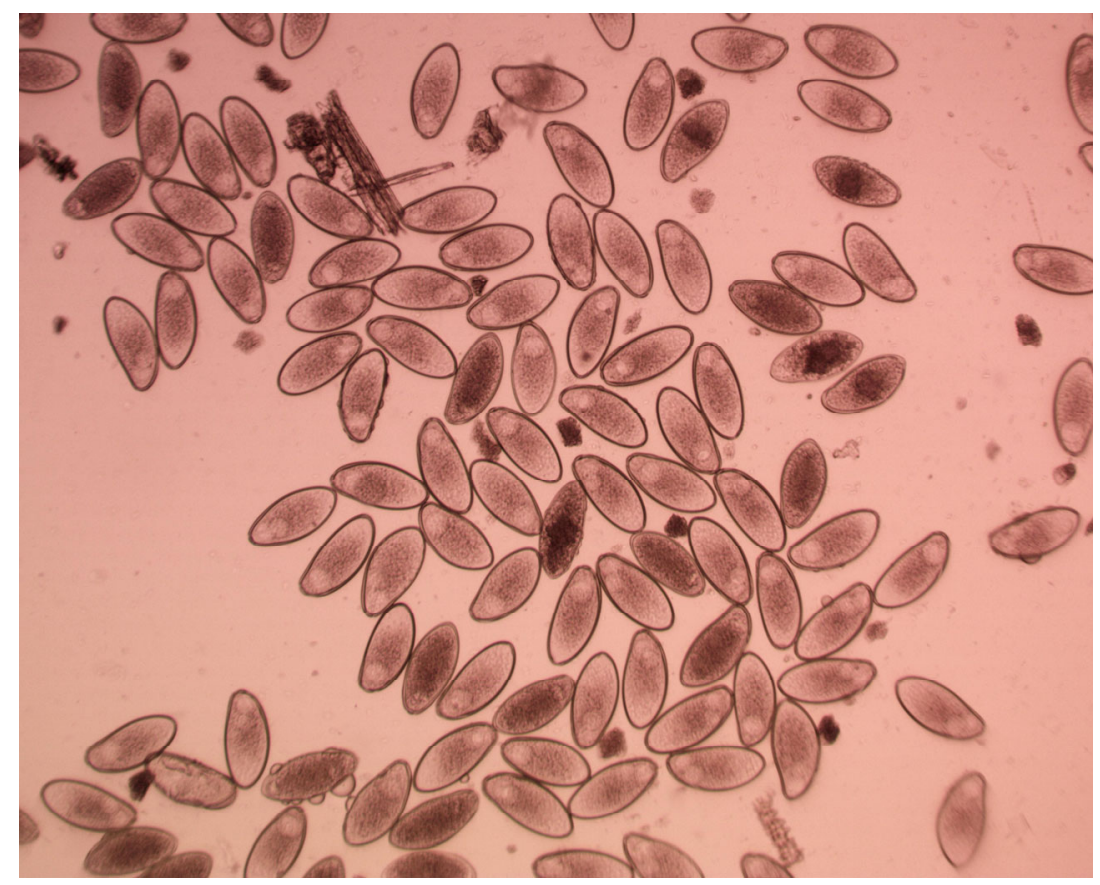

Рис. Культура яєць P. ambiguus, виділених з гонад самок пасалурисів, у поживному середовищі за використання удосконаленого способу $(\times 100)$

\section{Таблиця}

Порівняльна ефективність способів культивування яєць нематод виду P. ambiguus, $\mathrm{n}=20(\mathrm{M} \pm \mathrm{m})$

\begin{tabular}{|c|c|c|c|c|}
\hline \multirow{2}{*}{$\begin{array}{c}\text { Спосіб } \\
\text { дослідження }\end{array}$} & \multicolumn{3}{|c|}{ Кількість яєць на 5-у добу досліду } & \multirow{2}{*}{$\begin{array}{c}\text { \% яєць, що не досягли } \\
\text { інвазійної стадії }\end{array}$} \\
\hline & інвазійні & зупинилися в розвитку & загинули & \\
\hline Загальноприйнятий спосіб & $27,65 \pm 0,94$ & $26,20 \pm 1,36$ & $46,15 \pm 1,65$ & 72,35 \\
\hline Удосконалений спосіб & $\begin{array}{l}71,35 \pm 1,41 \\
* * *\end{array}$ & $\begin{array}{c}10,95 \pm 0,69 \\
* * *\end{array}$ & $\begin{array}{l}17,70 \pm 1,09 \\
* * *\end{array}$ & 28,65 \\
\hline
\end{tabular}

Примітка: *** $\mathrm{P}<0,001$ - порівняно $з$ показниками загальноприйнятого способу

За використання загальновідомого способу при підрахунку 100 яєць P. ambiguus в культурі впродовж культивування 27,65 яєць досягають інвазійної стадії, 26,20 яєць - зупинилися в розвитку, а 46,15 яєць гинули. Всього у процесі проведення експерименту $72,35 \%$ яєць пасалурисів у дослідній культурі не досягли інвазійної стадії. Водночас за використання удосконаленого способу на 100 підрахованих яєць P. ambiguus в культурі у середньому 71,35 яєць містили личинку всередині, тобто досягали інвазійної стадіï. Отримані результати свідчать про вищу ефективність (на $38,75 \%$, Р < 0,001) запропонованого нами способу культивування порівняно із результативністю загальновідомої методики. Встановлено, що за культивування яєць пасалурисів з використанням запропонованого методу виявлено 10,95 та 17,70 яєць, які зупинялися в розвитку та гинули відповідно, що на
41,79 й 38,35 \% (P < 0,001) менше порівняно із загальновідомим методом. Отже, отримані результати проведених експериментальних досліджень свідчать про високу ефективність запропонованого способу культивування яєць нематод P. ambiguus.

Більшість науковців свідчать, що збудник пасалурозу є одним 3 найбільш поширених нематодозів травного каналу домашніх кролів, який може спричинювати значні економічні збитки галузі, внаслідок схуднення тварин, зниження якості отриманої продукції від інвазованих кролів, зниження їх загальної резистентності (Allan et al., 1999; Szkuci et al., 2014; Hajipour \& Zavarshani, 2020). Отже, використанням тест-культур яєць нематод в експериментальних дослі-дженнях 3 метою вдосконалення існуючих заходів щодо боротьби та профілактики пасалурозу $\epsilon$ актуа-льним напрямом досліджень. У доступній літературі 
відсутні відомості щодо наявних методів культивування яєць P.ambiguus, що обумовлюе створення нових та ефективних способів отримання яєць пасалурисів на різних стадіях розвитку. Так, запропоновані методики культивування личинок і яєць гельмінтів та ооцист найпростіших та культивування яєць Trichuris muris (Astafiev et al., 1989; Mytrofanov et al., 2013). Однак недоліками цих методів є те, що для отримання культури яєць гельмінтів використовуються фекалії, що не $є$ доцільним для збудника P. ambiguus. Це пов'язано з тим, що у циклі розвитку самка відкладає яйця на шкіру прианальної ділянки кролів, а тому в фекаліях їх виявляють вкрай рідко та в малій кількості. Тому нами було удосконалено та запропоновано спосіб культивування яєць P. ambiguus, ефективність якого перевищувала ( $>$ < 0,001) результативність загальновідомого способу (Smirnov, 1927). Отже, запропонований спосіб дозволяє отримувати культуру яєць збудника пасалурозу кролів на різних стадіях розвитку та проводити експериментальні дослідження на тест-культурах щодо встановлення біологічних особливостей збудника та визначення дезінвазійної ефективності дезінфікуючих засобів.

\section{Висновки}

Удосконалений спосіб культивування яєць нематод Passalurus ambiguus, що паразитують у кролів, перевищував ефективність (на 38,75\%, Р < 0,001) загальновідомої методики за кількістю отриманих інвазійних яєць у процесі ембріогенезу. Запропонована методика дозволяє створити сприятливі умови, близькі до природних, для розвитку яєць пасалурисів in vitro, а також дозволяє проводити мікроскопію та мікрофотозйомку дослідної культури яєць безпосередньо на годинниковому скельці без вилучення їх iз субстрату.

Перспективи подальших досліджень. Перспективами подальших досліджень є вивчення впливу температури на ембріональний розвиток та життєздатність яєць нематод виду Passalurus ambiguus, що паразитують у кролів.

Відомості про конфлікт інтересів. Автори стверджують про відсутність конфлікту інтересів щодо їх вкладу та результатів досліджень.

\section{References}

Skrjabin, K. I. (1928). The method of complete helminthological autopsy of vertebrates, including humans. Moscow State University, Moscow (in Russian).

Cullere, M., \& Dalle Zotte, A. (2018). Rabbit meat production and consumption: State of knowledge and future perspectives. Meat Sience, 143, 137-146. doi: 10.1016/j.meatsci.2018.04.029.

Li, S., Zeng, W., Li, R., Hoffman, L. C., He, Z., Sun, Q., \& Li, H. (2018). Rabbit meat production and processing in China. Meat Sience, 145, 320-328. doi: 10.1016/j.meatsci.2018.06.037.
Dalle Zotte, A. (2002). Perception of rabbit meat quality and major factors influencing the rabbit carcass and meat quality. Livestock Production Science, 75(1),1132. doi: 10.1016/s0301-6226(01)00308-6.

Hernandez, A. D., Boag, B., Neilson, R., \& Forrester, N. L. (2018). Variable changes in nematode infection prevalence and intensity after rabbit haemorrhagic disease virus emerged in wild rabbits in Scotland and New Zealand. International Journal for Parasitology: Parasites and Wildlife, 7(2), 187-195. doi: 10.1016/j.ijppaw.2018.05.002.

Abdel-Gaber, R., Ataya, F., Fouad, D., Daoud, M., \& Alzuhairy, S. (2019). Prevalence, morphological and molecular phylogenetic analyses of the rabbit pinworm, Passalurus ambiguus Rudolphi 1819, in the domestic rabbits Oryctolagus cuniculus. Acta Parasitologica, 64(2), 316-330. doi: 10.2478/s11686019-00047-7.

Robinson, G., \& Chalmers, R. M. (2010). The european rabbit (Oryctolagus cuniculus), a source of zoonotic cryptosporidiosis. Zoonoses and Public Health, 57(78), 1-13. doi: 10.1111/j.1863-2378.2009.01308.x.

Boag, B. (1985). The incidence of helminth parasites from the wild rabbit Oryctolagus cuniculus (L.) in eastern Scotland. Journal of Helminthology, 59(1), 61-69. doi: 10.1017/s0022149x00034507.

Haupt, W., \& Hartung, J. (1984). Endoparasite infestation of the stomach and intestinal tract of feral rabbits from the Leipzig region. Angewandte Parasitologie, 25(2), 65-71.

Hajipour, N., \& Zavarshani, M. (2020). Ectoparasites and endoparasites of New Zealand white rabbits from North West of Iran. Iranian Journal of Parasitology, 15(2), 266-271. URL: https://www.ncbi.nlm.nih.gov/ pmc/articles/PMC7311816.

Mykhailiutenko, S. M., Kruchynenko, O. V., Klymenko, O. S., Serdioucov, J. K., Dmytrenko, N. I., \& Tkachenko, V. V. (2019). Pathomorphological changes in the large intestine of rabbits parasitised by Passalurus ambiguus (Nematoda, Oxyuridae). Regulatory Mechanisms in Biosystems, 10(1), 69-74. doi: $10.15421 / 021911$.

Lee, D. L. (2002). The biology of nematodes. Taylor \& Francis, London. doi: 10.1201/b12614.

Stroehlein, A. J., Young, N. D., Korhonen, P. K., Chang, B. C. H., Nejsum, P., Pozio, E., La Rosa, G., Sternberg, P. W., \& Gasser, R. B. (2017). Whipworm kinomes reflect a unique biology and adaptation to the host animal. International Journal for Parasitology, 47(13), 857-866. doi: 10.1016/j.ijpara.2017.04.005.

Astafiev, B. A., Jarockij, L. S., \& Lebedeva, M. N. (1989). Jeksperimental'nye modeli parazitozov v biologii i medicine. Nauka, Moskva (in Russian).

Smirnov, G. G. (1927). K voprosu o patologicheskih izmenenijah pri migracii askaridnyh lichinok $\mathrm{v}$ tele hozjaina. Jeksperimental'noe issledovanie. Izvestija Akademii nauk SSSR, 21(7), 1275-1298 (in Russian).

Mytrofanov, S. V., Soroka, N. M., \& Kychyljuk, Ju. V. (2013). Patent Ukrai'ny № 201212466. Sposib kul'tyvuvannja lychynok, jajec' gel'mintiv ta najprostishyh (25 kvitnja, 2013) (in Ukrainian). 
Allan, J. C., Craig, P. S., Sherington, J., Rogan, M. T., Storey, D. M., Heath, S., \& Iball, K. (1999). Helminth parasites of the wild rabbit Oryctolagus cuniculus near Malham Tarn, Yorkshire, UK. Journal of Helminthology, 73(4), 289-294. doi: 10.1017/s0022149x99000487.
Szkucik, K., Pyz-Łukasik, R., Szczepaniak, K. O., \& Paszkiewicz, W. (2014). Occurrence of gastrointestinal parasites in slaughter rabbits. Parasitology Research, 113(1), 59-64. doi: 10.1007/s00436-013-3625-7. 